\title{
PENGARUH CORPORATE SOCIAL RESPONSIBILITY DISCLOSURE(CSRD), NILAI PERUSAHAAN DAN PROFITABILITAS
}

\author{
Wendy Salim Saputra ${ }^{1}$, Temy Setiawan ${ }^{2}$ \\ ${ }^{l}$ (Universitas Bunda Mulia) \\ ${ }^{2}$ (Universitas Bunda Mulia)
}

\begin{abstract}
Latar belakang. Salah satu tujuan perusahaan adalah memenuhi kepentingan pemegang saham berupa peningkatan nilai perusahaan. Namun dalam upaya manajemen tersebut, tentunya penting sekali memperhatikan kepentingan sosial dan lingkungan agar tidak bersinggungan. Informasi atas CSRD memberikan signal pada nilai perusahaan.
\end{abstract}

Tujuan penelitian. Penelitian ini bertujuan memberikan bukti empiris pengaruh CSRD terhadap nilai perusahaan secara langsung dan efek moderasi profitabilitas.

Model penelitian. Populasi penelitian adalah seluruh perusahaan dalam industri maufaktur di dalam periode pengamatan 2014-2016. Teknik purposive sampling digunakan untuk menarik sampel. Data yang dianalisis sebanyak 100 data yang bersumber dari laporan tahunan perusahaan. Analisis menggunakan SPSS.

Hasil. Penelitian ini memberikan pembuktian empiris bahwa terdapat pengaruh negative CSRD terhadap nilai perusahaan dan profitabilitas memberikan pengaruh moderasi.

Kontribusi. Penelitian ini memberikan informasi bahwa CSRD di Indonesia untuk industri manufaktur belum memberikan signal positif bagi nilai perusahaan. Oleh karena itu perlu mengungkapkan CSRD pada laporan tersendiri sehingga informasi yang diungkapkan akan lebih luas yang diharapkan akan meningkatkan nilai perusahaan.

Kata kunci :CSRD, nilai perusahaan, profitabilitas, GRI 4, laporan tahunan

\begin{abstract}
Background.The main objective of the company is increasing the firm value. In other hand, the company should pay attention to social and environmental problems. It is a compulsory for the company to increase the social and environment performance. CSRD signals corporate value.

Research Objective. This study aims to provide empirical evidence of the influence of CSRD on corporate value directly and the effect of profitability as a moderate variable.

Research Design. The population of this study is all companies in the industry within the observation period 2014-2016. The purposive sampling technique is used. The data analyzed are 100 data sourced from the company's annual report. Analysis using SPSS.
\end{abstract}


Pengaruh Corporate Social Responsibility Disclosure (CSRD) terhadap Nilai Perusahaan dengan Profitabilitas Sebagai Variabel Moderasi

Results. This study provides empirical evidence that there is a negative effect of CSRD on firm value and profitability gives moderation influence.

Research Contribution. This study provides information that CSRD in Indonesia for the manufacturing industry has not given a positive signal for the value of the company. It is therefore necessary to disclose the CSRD in its own report so that the disclosed information will be broader which is expected to increase the value of the company.

\section{KEYWORDS-CSRD, firm value, profitability, GRI G4, annual report}

\section{Pendahuluan}

Setiap badan usaha memiliki tujuan jelas yang hendak dicapai (Merchant dan Stede, 2012). Salah satu tujuan perusahaan adalah menciptakan nilai bagi pemangku kepentingan yang salah satunya adalah pemegang saham (Harjito dan Agus, 2005). Nilai bagi pemegang saham dapat diukur dengan adanya peningkatan harga saham pada waktu yang panjang. Dengan harga saham meningkat, menunjukan kinerja manajemen memperoleh kepercayaan investor untuk tetap mempertahankan sahamnya atau menambah jumlah kepemilikan saham (Haruman, 2008; Kieso, Weygant dan Warfield, 2014). Oleh karena itu, penting sekali bagi manajemen di dalam meningkatkan nilai perusahaan yang tercermin dalam harga saham.

Peningkatan harga saham merupakan refleksi dari kinerja manajemen selama periode yang terukur. Kinerja manajemen tidak lagi dilihat pada bagaimana perusahaan menghasilkan laba namun juga bagaimana perusahaan mencapai nilai sosial dan lingkungan yang sejalan dengan konsep triple bottom line: profit, people planet(Elkington, 1997; Porter dan Kramer, 2011). Tuntutan pemangku kepentingan meluas seiiring dengan perkembangan teknologi dan informasi yang menyinggung aspek keberlanjutan (Cannon, 2012; Rankin, et al., 2012; Brinkmann, 2016). Oleh karena itu, perusahaan perlu memperhatikan upaya di dalam mencapai kinerja sosial dan lingkungan melalui aktivitas Corporate Social ResponsibilityCSR (Kamil dan Antonius, 2012; Rustiarini 2010; McWilliams dan Siegel, 2000).

Informasi atas keberhasilan perusahaan dalam menjalankan CSR diungkapkan kepada pemangku kepentingan di dalam laporan tahunan (Neu, Warsame dan Pendwell, 1998; 
Pengaruh Corporate Social Responsibility Disclosure (CSRD) terhadap Nilai Perusahaan dengan Profitabilitas Sebagai Variabel Moderasi

Halme, Huse, 1997; Santema,Van De Rijt, 2001). Pengungkapan perusahaan atas aktifitas CSR (CSR Disclosure-CSRD) merupakan media yang informatif bagi pemangku kepentingan seperti pemegang saham (Walter, 2014; Lii and Lee, 2012). Oleh karena itu, penting sekali bagi perusahaan di dalam menyusun informasi CSRD untuk meningkatkan nilai perusahaan (Rustiarini, 2010). Penelitian ini bertujuan untuk melihat pengaruh CSRD terhadap nilai perusahaan.

Selain pengujian langsung CSRD terhadap nilai perusahaan, penelitian ini juga bertujuan memberikan bukti empiris bahwa profitabilitas akan memperkuat hubungan CSRD terhadap nilai perusahaan. Profitablitas memiliki pengaruh terhadap nilai perusahaan karena apabila perusahaan dapat mencapai kinerja profitabilitas yang baik, tentunya meningkatkan kepercayaan pemegang saham atau calon pemegang saham untuk mempertahankan dan menambah kepemilikan (Brigham dan Houston, 2006; Sayekti dan Wondabio, 2007). Hal ini akan memberikan signal pada peningkatan harga saham yang mencerminkan nilai perusahaan.

\section{Kerangka TeOri Dan Pengembangan Hipotesis}

\section{Stakeholder Theory}

Hadi (2011) Stakeholder Theory menjelaskan bahwa perusahaan bukanlah suatu entitas yang hanya beroperasi untuk kepentingannya sendiri namum harus memberikan manfaat bagi stakeholder. Dengan demikian, keberadaan suatu perusahaan sangat dipengaruhi oleh dukungan yang diberikan oleh stakeholder kepada perusahaan. Stakeholder merupakan semua pihak, internal maupun eksternal, yang dapat mempengaruhi ataupun dipengaruhi oleh perusahaan baik secara langsung maupun tidak langsung. Stakeholder theory menjadi dasar CSR perusahaan dan pengungkapannya untuk kepentingan seluruh stakeholder (Ardianto dan 
Pengaruh Corporate Social Responsibility Disclosure (CSRD) terhadap Nilai Perusahaan dengan Profitabilitas Sebagai Variabel Moderasi

Machfudz, 2011). Keterkaiatan teori ini dengan penelitian, menjelaskan bagaimana perusahaan memenuhi ekspektasi pemegang saham dengan tidak mengabaikan kepentingan pemangku kepentingan lainnya seperti karyawan, masyarakat, pelanggan dan lingkungan.

\section{Signalling Theory}

Signalling Theory membahas mengenai dorongan perusahaan untuk mengungkapkan informasi kepada pihak eksternal karena terjadi asimetri informasi antara manajemen dengan pihak eksternal. Oleh sebab itu, semua informasi perusahaan, baik itu informasi keuangan maupun non keuangan harus diungkapkan oleh perusahaan. Salah satu informasi tersebut adalah aktivitas CSR di dalam laporan tahunan. CSRD akan memberikan signal bagi peningkatan nilai perusahaan (Rustiarini, 2010).

\section{Nilai Perusahaan}

Nilai perusahaan dibentuk melalui indikator nilai pasar saham sangat dipengaruhi oleh peluang-peluang investasi. Adanya peluang investasi dapat memberikan sinyal positif tentang pertumbuhan perusahaan di masa yang akan datang sehingga dapat meningkatkan nilai perusahaan (Rustiarini, 2010; Haruman, 2008).Pengukuran atas nilai perusahaan menggunakan rumus Tobin's Q.

\section{Corporate Social Responsibility Disclosure (CSRD)}

Pengungkapan CSR perusahaan akan dijelaskan dalam laporan CSR yang dapat terintegrasi dalam laporan tahunan. Laporan CSR merupakan pengungkapan perusahaan yang mendemonstrasikan proses inklusi aspek sosial dan lingkungan di dalam operasi bisnis serta interaksinya dengan pemangku kepentingan. Informasi yang diungkap dalam laporan CSR 
Pengaruh Corporate Social Responsibility Disclosure (CSRD) terhadap Nilai Perusahaan dengan Profitabilitas Sebagai Variabel Moderasi

adalah bagian interaksi dari perusahaan yang beretika dengan pemangku kepentingannya sebagai wujud legitimasi atas perilaku perusahaan dan akan berdampak pada reputasi positif perusahaan (Michelon, 2011; Othman et al., 2011; Li, Wang dan Cai, 2011; Colleoni, 2013). Adanya reputasi positif perusahaan maka akan berdampak pada kinerja pasar (Garriga dan Mele, 2004). Oleh karena itu penting sekali CSD perusahaan dalam menjaga eksistensi jangka panjang melalui reputasi perusahaan untuk meningkatkan nilai perusahaan.

\section{Profitabilitas}

Bringham dan Houston (2006) menjelaskan bahwa profitabilitas merupakan kemampuan perusahaan menghasilkan laba dalam hubungannya dengan penjualan, total asset ataupun modal sendiri. Pentingnya rasio profitabilitas mencerminkan kinerja finansial karena salah satu tolak ukur kelangsungan usaha adalah laba. Apabila perusahaan tidak menghasilkan laba maka perusahaan orientasi bisnis harus berhenti beroperasi. Profitabilitas selain menjadi ukuran performa manajemen yang diukur secara finansial, dapat menjadi cadangan modal sendiri serta memberikan persepsi positif bagi pemangku kepentingan terhadap perusahaan.

Rasio profitabilitas membandingkan laba yang diperoleh pada periode berjalan terhadap penjualan periode tersebut, total asset ataupun ekuitas pada laporan posisi keuangan. Efektifitas rasio profitabilitas diukur dengan nilai yang semakin besar semakin baik. Analisis profitabilitas lebih dari ukuran akuntansi seperti penjualan, harga pokok penjualan serta beban operasi dan beban nonoperasi untuk menilai sumber daya. Hasil penilaian ini dapat mengestimasi pengembalian dan karakteristik risiko perusahaan dengan lebih baik. Analisis profitabilitas juga memungkinkan untuk membedakan antara kinerja yang terkait dengan 
Pengaruh Corporate Social Responsibility Disclosure (CSRD) terhadap Nilai Perusahaan dengan Profitabilitas Sebagai Variabel Moderasi

keputusan operasi dan kinerja terkait dengan keputusan pendanaan dan investasi (Wheeler, Colbert dan Freeman, 2003).

\section{Pengajuan Hipotesis}

Bowen (1943) dalam Rosiana (2013) menyatakan bahwa keberhasilan dunia bisnis ditentukan oleh bagaimana kontribusinya terhadap kesejahteraan masyarakat umum, bukan hanya untuk warga bisnis itu sendiri. Suatu entitas dalam menjalankan usahanya tidak terlepas dari masyarakat dan lingkungan sekitarnya, sehingga menciptakan hubungan timbal balik antara masyarakat dan perusahaan. Perusahaan membutuhkan suatu respon yang positif dari masyarakat yang diperoleh melalui apa yang dilakukan oleh perusahaan kepada para stakeholder, termasuk masyarakat dan lingkungan sekitar (Kamil dan Antonius, 2012). Menurut Narver (1971) dalam McWilliams dan Siegel (2000), kondisi keuangan ternyata tidak cukup untuk menjamin nilai perusahaan tumbuh secara berkelanjutan. Keberlanjutan perusahaan (corporate sustainability) hanya akan terjamin apabila perusahaan memperhatikan dimensi sosial dan lingkungan hidup. Sudah menjadi fakta bagaimana reaksi masyarakat sekitar terhadap perusahaan yang dianggap tidak memperhatikan lingkungan. Perusahaan perlu melakukan pengungkapan terhadap lingkungan di sekitar perusahaan.

\section{Ha1 : Corporate Social Responsibility berpengaruh terhadap Nilai Perusahaan}

Kamil dan Herusetya (2012) dalam Rosiana dkk (2013), berpendapat bahwa tingkat profitabilitas yang semakin besar menunjukkan perusahaan mampu mendapatkan laba yang semakin besar, sehingga perusahaan mampu untuk meningkatkan aktivitas tanggung jawab sosial, serta mengungkapkan tanggung jawab sosialnya dalam laporan tahunan dengan lebih luas. 
Pengaruh Corporate Social Responsibility Disclosure (CSRD) terhadap Nilai Perusahaan dengan Profitabilitas Sebagai Variabel Moderasi

\section{Ha2: Profitabilitas memoderasi pengaruh hubungan Coporate Social Responsibility terhadap Nilai Perusahaan}

\section{Metodologi Penelitian}

Penelitian ini merupakan penelitian kuantitatif asosiatif kausalitas yang memberikan pembuktian secara empiris pengaruh CSRD terhadap nilai perusahaan dan efek moderasi dari profitabilitas. Populasi adalah seluruh perusahaan listing di Bursa Efek Indonesia (BEI) tahun 2014-2016. Pemilihan sampel dengan purposive sampling. Penelitian ini menggunakan data sekunder yaitu laporan tahunan. Semua data yang diperoleh harus mempunyai kaitan dengan penelitian ini serta data-data yang mendukung penelitian ini antara lain closing price akhir tahun, jumlah saham yang beredar, nilai buku ekuitas, nilai buku hutang, item pengungkapan CSR, total asset, laba bersih. Pengumpulan data dengan studi dokumen laporan tahunan. Analisis data menggunakan SPSS.

\section{Tabel 1. Operasionalisasi Variabel}

\begin{tabular}{|c|c|c|c|}
\hline No & Variabel & Pengukuran & Skala \\
\hline 1 & Nilai Perusahaan & Tobin's Q & Rasio \\
\hline 2 & CSRD & $\begin{array}{c}\text { Index Pengungkapan } \\
\text { berdasarkan GRI G4 (Indikator } \\
\text { Pengungkapan Aspek Ekonomi, } \\
\text { Aspek Lingkungan dan Aspek } \\
\text { Sosial) }\end{array}$ & Rasio \\
\hline 3 & Profitabilitas & ROA & Rasio \\
\hline
\end{tabular}

Sumber: Olahan Peneliti

\section{HASIL}

Pada pengolahan data dengan SPSS perlu dilakukan pengujian atas normalitas dan asumsi klasik. Setelah dilakukan pengujian, data yang diolah telah lolos uji normalitas dan bebas dari masalah asumsi klasik. Total data yang diolah adalah sebanyak 168 data observasi. 
Pengaruh Corporate Social Responsibility Disclosure (CSRD) terhadap Nilai Perusahaan dengan Profitabilitas Sebagai Variabel Moderasi

Pengujian selanjutnya adalah uji regresi berganda, uji koefisien determinan, uji $\mathrm{F}$ dan uji $\mathrm{t}$ untuk melakukan pembuktian hipotesis.

\section{Tabel 2.Hasil Uji Regresi Berganda}

\begin{tabular}{|c|c|c|c|c|c|c|}
\hline \multirow{2}{*}{\multicolumn{2}{|c|}{ Model }} & \multicolumn{2}{|c|}{ Unstandardized Coefficients } & $\begin{array}{l}\text { Standardized } \\
\text { Coefficients }\end{array}$ & \multirow[b]{2}{*}{$\mathrm{t}$} & \multirow[b]{2}{*}{ Sig. } \\
\hline & & $\mathrm{B}$ & Std. Error & Beta & & \\
\hline \multirow[t]{3}{*}{1} & (Constant) & 1,968 &, 321 & & 6,139 &, 000 \\
\hline & CSR & $-3,468$ & 1,077 &,- 293 & $-3,220$ &, 002 \\
\hline & CSR*ROA & 31,849 & 4,309 & ,549 & 7,391 & ,000 \\
\hline
\end{tabular}

Sumber: Pengolahan data SPSS 22

Berdasarkan tabel 2. diperoleh hasil persamaan regresi linier berganda sebagai berikut:

$\mathrm{Y}=1,968-3,468 \mathrm{X}_{1}+31,849 \mathrm{X}_{1} \mathrm{X}_{2}+\mathrm{e}$

Persamaan diatas dapat dijelaskan nilai konstanta yang diperoleh sebesar 1,968. Hal ini berarti bahwa jika variabel independen (corporate social responsibility dan profitabilitas) adalah nol, maka besarnya nilai perusahaan adalah sebesar konstanta 1,968. Nilai koefisien regresi variabel profitabilitas (X1) sebesar -3,468. Hal ini menandakan bahwa setiap peningkatan satu satuan profitabilitas akan mengakibatkan penurunan nilai perusahaan sebesar 3,468. Nilai koefisien regresi variabel profitabilitas $\left(\mathrm{X}_{1} \mathrm{X}_{2}\right)$ sebesar 31,849. Hal ini menandakan bahwa setiap peningkatan satu satuan interaksi antara Corporate Social Responsibiliy dengan profitabilitas akan mengakibatkan kenaikan nilai perusahaan sebesar 31,849 .

Tabel 3.Hasil Analisis Adjusted R-square

\begin{tabular}{ll}
\hline Model & Adjusted $R$-square \\
\hline 1 & 0,240 \\
\hline \multicolumn{2}{c}{ Sumber: Pengolahan data SPSS 22}
\end{tabular}

Seperti yang terlihat pada tabel 3. nilai adjusted $R$-square sebesar 0,240 yang berarti variasi variabel dependen nilai perusahaan dapat dijelaskan oleh variasi variabel independen corporate social responsibility dan profitabilitas sebesar $24 \%$ sedangkan sisanya sebesar $76 \%$ 
Pengaruh Corporate Social Responsibility Disclosure (CSRD) terhadap Nilai Perusahaan dengan Profitabilitas Sebagai Variabel Moderasi

dijelaskan variabel-variabel lain yang dianggap tetap dan tidak dimasukkan ke dalam model penelitian ini.

\section{Tabel 4.Hasil Uji F}

\begin{tabular}{lcc}
\hline Model & F & Sig \\
\hline 1 & 27,326 & 0,000 \\
\hline \multicolumn{4}{l}{ Sumber: Pengolahan data SPSS 22}
\end{tabular}

Hasil pengujian uji F yang dapat dilihat pada tabel 4. menunjukkan nilai sig 0,000. Nilai sig nya lebih kecil dari 0,05 berarti model fit. Hal ini menunjukkan data layak digunakan dalam model penelitian.

Tabel 5.Hasil Uji t

\begin{tabular}{|c|c|c|c|c|c|c|}
\hline \multirow{2}{*}{\multicolumn{2}{|c|}{ Model }} & \multicolumn{2}{|c|}{ Unstandardized Coefficients } & $\begin{array}{l}\text { Standardized } \\
\text { Coefficients }\end{array}$ & \multirow[b]{2}{*}{$\mathrm{t}$} & \multirow[b]{2}{*}{ Sig. } \\
\hline & & $B$ & Std. Error & Beta & & \\
\hline \multirow[t]{3}{*}{1} & (Constant) & 1,968 & ,321 & & 6,139 &, 000 \\
\hline & CSR & $-3,468$ & 1,077 &,- 293 & $-3,220$ &, 002 \\
\hline & CSR*ROA & 31,849 & 4,309 &, 549 & 7,391 &, 000 \\
\hline
\end{tabular}

Sumber: Pengolahan data SPSS 22

Berdasarkan hasil uji t pada tabel 5. maka dapat dilihat bahwa hasil variabel CSRD dengan tingkat signifikansi senilai 0,002 yaitu lebih kecil dari 0,05 sehingga hasil penelitian ini menyatakan bahwa nilai perusahaan dipengaruh oleh $\operatorname{CSRD}\left(\mathrm{Ha}_{1}\right.$ diterima $)$. Namun CSRD tampak berpengaruh negatif terhadap nilai perusahaan. Hal ini berarti setiap peningkatan pengeluaran perusahaan untuk CSRD yang tidak diikuti dengan perubahan rasio keuangan lain dari suatu perusahaan seperti profitabilitas, ukuran perusahaan, leverage, pertumbuhan dan rasio lainnya menyebabkan investor menilai bahwa peningkatan pengeluaaran untuk 
Pengaruh Corporate Social Responsibility Disclosure (CSRD) terhadap Nilai Perusahaan dengan Profitabilitas Sebagai Variabel Moderasi

corporate social responsibility merupakan suatu pemborosan sumber daya perusahaan sehingga semakin meningkat CSRD akan menurunkan nilai perusahaan. Hasil ini konsisten dengan Handriyani dan Andayani (2013), Rosiana, et al (2013), serta Rustiarini (2010) yang menyatakan bahwa variabel corporate social responsibility memiliki pengaruh terhadap nilai perusahaan.

Hasil estimasi variabel moderasi profitabilitas dengan nilai signifikansi 0,000 yaitu dibawah 0,05. Berarti pengaruh pengungkapan corporate social responsibility terhadap nilai perusahaan mampu dimoderasi (diperkuat) oleh variabel profitabilitas. Seperti pendapat yang diungkapkan Heinze (1976) dalam Rosiana et al (2013) bahwa profitabilitas merupakan faktor yang menjadikan manajemen lebih bebas dan fleksibel dalam mengungkapkan corporate social responsibility kepada shareholder. Profitabilitas yang semakin tinggi akan membuat manajemen dapat melakukan dan mengungkapkan aktivitas corporate social responsibility secara lebih luas. Hasil penelitian ini konsisten dengan penelitian Rosiana et al (2013) yang menyatakan bahwa profitabilitas dapat memoderasi hubungan hubungan corporate social responsibility terhadap nilai perusahaan. Namun hasil penelitian ini tidak konsisten dengan hasil penelitian Handriyani dan Andayani (2013) yang menyatakan bahwa profitabilitas tidak dapat memoderasi hubungan antara corporate social responsibility terhadap nilai perusahaan.

\section{SimpUlan, DAN SARAN}

Penelitian ini memberikan bukti empiris bahwa pengungkapan perusahaan atas CSR (CSRD) akan berpengaruh negatif terhadap nilai perusahaan. Selain itu profitabilitas mampu memoderasi pengaruh CSRD terhadap nilai perusahaan. Pada penelitian ini tampak bahwa 
Pengaruh Corporate Social Responsibility Disclosure (CSRD) terhadap Nilai Perusahaan dengan Profitabilitas Sebagai Variabel Moderasi

pada industri manufaktur, CSRD masih dianggap sebagai suatu beban perusahaan yang pada akhirnya akan menurunkan nilai perusahaan bagi pemegang saham. Hal ini perlu menjadi perhatian bagi pelaku bisnis di dalam bidang manufaktur untuk meningkatkan kesadaran bahwa orientasi bisnis saat ini tidak hanya pada pencapaian profit tetapi juga pada people dan planet. Pengungkapan CSR di dalam laporan tahunan berupa CSRD merupakan wujud pertanggungjawaban manajemen dalam pencapaian kinerja aspek lingkungan dan sosial. Adanya apresiasi atas pencapaian manajemen, kelak akan mendorong motivasi di dalam peningkatan laba yang mengarah pada nilai perusahaan.

Keterbatasan pada penelitian ini, pengungkapan diukur menggunakan indikator GRI G4 pada laporan tahunan. Hal ini menyebabkan kendala pada pengukuran pengungkapan. Penelitian lebih lanjut, dapat menggunakan indikator lain pada pengungkapan aspek keberlanjutan dengan laporan tahunan sebagai objek penelitian. Selain itu pula, sebaiknya melakukan pengujian empiris untuk industri yang lain. Saran bagi industri, mempertahankan CSRD namun tidak hanya diintegrasikan dalam laporan tahunan namun menyusun laporan tersendiri seperti laporan keberlanjutan.

\section{DAFTAR REFERENSI}

Ardianto, E. dan D. M. Machfudz. 2011. M. Efek Kedermawanan Pebisnis dan CSR. Jakarta: Kompas Gramedia.

Brigham, Eugene F. dan Joel F Houston. 2006. "Dasar-Dasar Manajemen Keuangan". Jakarta06Salemba Empat

Brinkmann, R. (2016). Introduction to Sustainability. Singapore: Wiley.

Cannon, Tom. (2012). Corporate Responsibility 2nd Edition. England: Pearson. 
Pengaruh Corporate Social Responsibility Disclosure (CSRD) terhadap Nilai Perusahaan dengan Profitabilitas Sebagai Variabel Moderasi

Colleoni, E. (2013). CSR communication strategies for organizational legitimacy in social media. Corporate Communications: An International Journal, Vol. 18 No. 2, pp. 228248.

Elkington, J. (1997), Cannibals with forks: the triple bottom line of 21st century business, Capstone, Oxford.

Garriga, E., and Mele, D. (2004). Corporate social responsibility theories: mapping the territory. Journal of Business Ethics, 53:51-71.

Hadi, Nor. 2011. Corporate Social Responsibility. Yogyakarta: Graha Ilmu.

Halme M, Huse M. (1997). The influence of corporate governance, industry and country factors on environmental reporting. Scandinavian Journal of Management 13(2):pp.137-157.

Handriyani, Arik Novia dan Andayani. 2013. Pengaruh Corporate Social Responsibility terhadap Nilai Perusahaan dengan Profitabilitas sebagai Variabel Moderating. Jurnal Ilmu \& Riset Akuntansi, Vol. 2 No. 5.

Harjito, M. d., \& Agus. (2005) Manajemen Keuangan edisi pertama, Jakarta: Jala Sutia.

Haruman, Tendi. 2008. "Pengaruh Struktur Kepemilikan Terhadap Keputusan Keuangan dan Nilai Perusahaan". Pontianak: Simposium Nasional.

January-Februari, 2-17.

Kamil, Ahmad dan Antonius Herusetya. 2012. Pengaruh Karakteristik Perusahaan Terhadap Luas Pengungkapan Kegiatan Corporate Social Responsibility. Media Riset Akuntansi, 2(1), h: 1-17.

Kieso, D., Weygant, J.J., Warfield, T.D. (2014). Internediate Accounting. $2^{\text {nd }}$. Singapore: Wiley.

Li, X. G., Wang, X., \& Cai, J. Y. (2011). Corporate-, product-, and user-image dimensions and purchase intentions: the mediating role of cognitive and affective attitudes. Journal of Computers, 6(9), 1875-1879.

Lii, Y. and Lee, M. (2012), Doing right leads to doing well: when the type of csr and reputation interact to affect consumer evaluations of the firm. Journal of Business Ethics, Vol. 105(1), pp. 69-81.

McWilliams , Abagail and Donald Siegel. 2000. "Corporate Social Responsibility and Financial Performance: Correlation or Misspecification?”. Journal of Strategic Management, Vol. 21 No. 5. 603-609.

Merchant, Kenneth A. and Van der Stede, Wim. A. (2012). Management Control System Performance Measurement, Evaluation, and Incentives. England: Pearson Education Limited 
Pengaruh Corporate Social Responsibility Disclosure (CSRD) terhadap Nilai Perusahaan dengan Profitabilitas Sebagai Variabel Moderasi

Michelon, G. (2011), Sustainability disclosure and reputation: a comparative study. Corporate Reputation Review, Vol. 14 (2), pp. 79-96.

Neu P, Warsame H, Pendwell K. (1998). Managing public impressions: environmental disclosures in Annual Reports. Accounting, Organizations and Society 23(3):pp.26582.

Othman, S., Darus, F. and Arshad, R. (2011), The influence of coercive isomorphism on corporate social responsibility reporting and reputation. Social Responsibility Journal, Vol. 7 (1), pp. 118-135.

Porter, E. M., \& Kramer, M. R. (2011). Creating shared value. Harvard Business Review,

Rankin, M., Stanton, P., McGowan, S., Ferlauto, K., Tilling, M. (2012). Contemporary Issues in Accounting. Australia: John Wiley and Sons.

Rosiana, Gusti Ayu Made Ervina dan Gede Juliarsa, Maria M. Ratna Sari. 2013. "Pengaruh Pengungkapan CSR terhadap Nilai Perusahaan dengan Profitabilitas sebagai Variabel Pemoderasi”. Jurnal Akuntansi, Vol. 5 No. 3. Hal. 723 - 738. Bali : Universitas Udayana.

Rustiarini, Ni Wayan. 2010. "Pengaruh Corporate Governance Pada Hubungan Corporate Social Responsibility dan Nilai Perusahanan”. Simposium Nasional Akuntansi XIII. AKPM_12.

Santema S, Van De Rijt J. (2001). Strategy disclosure in Dutch Annual Reports. European Management Journal 19(1):pp.101-108.

Sayekti, Yosefa dan Ludovicus Sensi Wondabio. 2007. "Pengaruh CSR Disclosure terhadap Earning Response Coefficient”. Simposium Nasional Akuntansi X, Makasar, 26-28 Juli.

Walter, B. L, (2014). Corporate Social Responsibility Communication: Towards a Phase Model of Strategic Planning In Communicating Corporate Social Responsibility: Perspectives and Practice. Published online: 25 Sep 2014; 59-79.

Wheeler, D., B. Colbert, and R. E. Freeman. (2003). 'Focusing on Value: Reconciling Corporate Social Responsibility, Sustainability and a Stakeholder Approach in a Network World'. Journal of General Management, 28 (3): 1-29. 